\title{
Markers of follicle function in Belclare-cross ewes differing widely in ovulation rate
}

\author{
K. Reynaud ${ }^{1}$, J. P. Hanrahan ${ }^{2}$, A. Donovan ${ }^{2}$ and M. A. Driancourt ${ }^{1 *}$ \\ ${ }^{1}$ INRA-URA CNRS 1291, PRMD, 37380 Monnaie, France; and 'TEAGASC, Research Centre, Athenry, County Galway, Ireland
}

\begin{abstract}
High prolificacy due to a gene that has a large effect on ovulation rate has been noted in Booroola and Inverdale ewes. High prolificacy in the Belclare breed (a composite developed from stocks selected for very large litter size or high ovulation rate) may be related to the segregation of two genes. The aims of this study were (i) to compare the morphological and functional features of ovulatory follicles from carriers (which could only be heterozygous for the genes of interest) and non-carriers, and (ii) to identify markers of the Belclare genes among secreted or cellular ovarian proteins. Belclare carrier ewes had more ovulatory follicles $(4.9 \pm 0.4)$ than did non-carrier ewes $(2.0 \pm 0.2)$ $(P<0.001)$. Ovulatory follicles from carriers were also smaller $(4.4 \pm 0.1 \mathrm{~mm}$ versus $5.7 \pm 0.2 \mathrm{~mm}, P<0.001)$ and contained a significantly reduced number of granulosa cells $(P<0.001)$. However, the proportion of proliferating granulosa cells in ovulatory follicles was similar in both groups. The in vitro secretion of steroids per follicle was only marginally lower in follicles from Belclare carriers compared with non-carriers. Furthermore, similar concentrations of steroidogenic enzymes were present in both groups, indicating that steroidogenic potential per granulosa cell is similar between carriers and non-carriers. Possible markers of the Belclare genes were identified among cellular proteins of follicular walls by two-dimensional PAGE and image analysis. Two spots at 78 and $49 \mathrm{kDa}$ were always absent in samples from non-carriers. When secreted proteins in follicles from carriers were compared with those from non-carriers, two spots at 53 and $41 \mathrm{kDa}$ were restricted to samples from carriers and three spots at 97,91 and $45 \mathrm{kDa}$ were unique to samples from non-carriers. Interestingly, the spot at $91 \mathrm{kDa}$ is also affected by the Booroola gene.
\end{abstract}

\section{Introduction}

The high ovulation rate of prolific sheep breeds may be due to several genes with small effects (Romanov, Finn) or to major genes (Fec ${ }^{\mathrm{B}}$, Booroola; $\mathrm{Fec}^{\mathrm{X}}$, Inverdale) (Davis et al., 1982, 1991; Piper and Bindon, 1982). Homozygous Inverdale ewes, but not homozygous Booroola ewes, are sterile (Davis et al., 1992). The Belclare breed is a composite developed from stocks that were selected for very large litter size or high ovulation rate (Hanrahan, 1990). Ewes with unusually high ovulation rates were detected in the Belclare population, and among the descendants of these ewes the repeatability of ovulation rate was very high (Hanrahan, 1990). This indicated that a major gene like the Booroola gene was segregating, and this was subsequently confirmed by segregation analysis. Recent evidence from interbreeding the descendants of these exceptional ewes has revealed the presence of a recessive gene that causes ovarian hypoplasia. Although this condition is analogous to that associated with the Inverdale gene, the available evidence is not consistent

${ }^{*}$ Correspondence.

Revised manuscript received 7 December 1998. with an X-linked mode of inheritance (Hanrahan, 1997). It is also evident that there is not full correspondence between the major gene for ovulation rate and the gene responsible for ovarian hypoplasia. Thus, ewes and rams known to be carriers of the gene for ovarian hypoplasia do not always have a high ovulation rate or are classified as non-carriers on the basis of progeny tests, respectively. However, the emergence of ovarian sterility among the descendants of ewes with exceptionally high ovulation rates indicates that there is some interaction between the loci involved in ovulation rate or that these loci are linked. Thus, Belclare sheep represent an original model for the study of the physiological factors that control ovulation rate.

Two main factors control ovulation rate: systemic concentrations of gonadotrophins and intraovarian factors (Webb et al., 1998). In Booroola ewes, high gonadotrophin concentrations (McNatty et al., 1987) together with possible alterations in intraovarian mechanisms (Fry et al., 1988; Driancourt et al., 1996) result in the ovulatory follicles of carriers being smaller, with fewer granulosa cells, but with an unaltered ability to produce steroids. In Inverdale ewes, no differences in gonadotrophin concentrations have been observed between non-carrier and heterozygous carrier 
ewes (Shackell et al., 1993). Hence, it is likely that alterations in intraovarian mechanisms generate the changes in ovarian function observed in heterozygous carriers (small ovulatory follicles containing a smaller number of granulosa cells). Recent data (Hanrahan, 1997) demonstrated that Belclarecross ewes classified as either heterozygous carriers (mean ovulation rate 5.5) or non-carriers (mean ovulation rate 2.2) of the major gene for ovulation rate yielded no evidence for differences in either LH or FSH during the periovulatory period or for plasma FSH after ovariectomy. This indicates that alterations in intraovarian regulation are a more likely explanation of the differences in ovulation rate than gonadotrophin concentrations.

Therefore, the aims of this study were (i) to examine morphological (size, number of granulosa cells) and functional features (in vitro steroid production and concentrations of steroidogenic enzymes in follicular walls) of large ovulatory follicles from carriers and non-carriers, and (ii) to identify possible markers of the genes (which could also act as local regulators of ovarian function) segregating in the Belclare population by comparing the pattern of cellular and secreted proteins by two-dimensional PAGE and image analysis.

\section{Materials and Methods}

\section{Animals}

Segregation analysis of ovulation rate data collected in a progeny testing programme using rams descended from Belclare ewes with exceptionally high ovulation rates (Hanrahan, 1990) led to rejection of the hypothesis that the variation in ovulation rate could be attributed to polygenic variation. The segregation analysis procedures used were those of Elsen and Le Roy (1990), developed for application to discrete traits. The animals used in the present study were chosen from a set of ewes produced by two rams shown to be carriers of a gene with a large effect on ovulation rate on the basis of the segregation analysis (J. P. Hanrahan, unpublished). These two rams were sired by Texels and were maternal half siblings born to a Belclare ewe that had a natural ovulation rate $\geq 15$ on a number of occasions. Because the Texel is a very low prolificacy breed, the offspring could only be heterozygous carriers of the major gene. The progeny testing programme involved mating potential carrier rams with Galway ewes (a low prolificacy breed). The lifetime records for ovulation rate (measured by laparoscopy; two consecutive cycles in each of 3 to 4 years for 60 ewes available for study) were used to identify those ewes with the highest (carriers) and lowest (non-carriers) ovulation rates to maximize the probability that the ewes were either carriers or non-carriers. Carrier and non-carrier ewes were chosen from the available progeny of both rams to avoid confounding any background genetic differences between the two rams. The two rams were also known to be carriers of the gene responsible for ovarian hypoplasia. It is recognized that the criteria used for classification of the ewes as carriers and non-carriers are related to the ovulation rates of the ewes. However, the magnitude of the differences can only be attributed to a gene locus with a large effect on ovulation rate (see below).

\section{Materials}

Culture media (minimal essential medium (MEM) and methionine free medium) were obtained from Sigma (St Quentin, Fallavier). ${ }^{35}$ [S]Methionine was purchased from NEN (Les Ulis). Acrylamide, bisacrylamide and urea were obtained from Biorad (Ivry-sur-Seine) and ampholines were acquired from BDH (Poole).

\section{Experiment 1: characterization of in vitro steroidogenesis and granulosa cell number}

Animals. The oestrous cycles of five non-carriers and five carriers were synchronized early in the breeding season using intravaginal progestagen pessaries (60 mg MAP; J\&M Veterinary, Dublin) that were inserted for 12 days. On days 6-8 of the subsequent oestrous cycle, luteolysis was induced

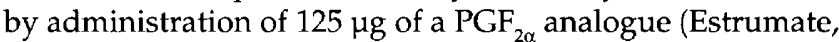
Schering, Dublin) and 33 to $38 \mathrm{~h}$ later ewes were ovariectomized under general anaesthesia, induced by $0.6 \mathrm{~g}$ sodium thiopental i.v. (Specia; Rhone Poulenc, Montrouge), to obtain follicles for culture.

Follicle culture. Large follicles $(\geq 3 \mathrm{~mm}$ ) from each ewe were dissected and measured using a micrometer. They were then transferred individually to 24-well plates containing $1 \mathrm{ml} \mathrm{MEM} \mathrm{(Sigma,} \mathrm{La} \mathrm{Verpillière)} \mathrm{and} \mathrm{incubated} \mathrm{for} 1 \mathrm{~h}$ at $38^{\circ} \mathrm{C}$ in $95 \%$ air and $5 \% \mathrm{CO}_{2}$. This system has been described and validated by Webb and England (1982) and Webb et al. (1989). At the end of the incubation, the follicles were fixed for histological examination to determine the total number of granulosa cells and their proliferative index. Incubation medium was stored at $-20^{\circ} \mathrm{C}$ before assay for oestradiol, progesterone and testosterone.

Assays. The concentrations of oestradiol, progesterone and testosterone in the incubation medium were quantified in single assays using validated radioimmunoassays (Terqui et al., 1988; Hochereau-de-Reviers et al., 1990). The intraassay coefficients of variation were $9.7,5.7$ and $10.7 \%$ for oestradiol, progesterone and testosterone, respectively. Minimum detectable values for oestradiol, progesterone and testosterone were $20.0 \mathrm{pg} \mathrm{ml}^{-1}, 0.1 \mathrm{ng} \mathrm{ml}^{-1}$ and $0.2 \mathrm{ng} \mathrm{ml}^{-1}$, respectively.

Follicle morphology and granulosa cell number. After the incubation period, the follicles were fixed in $4 \%(\mathrm{w} / \mathrm{v})$ paraformaldehyde, dehydrated and embedded in paraffin wax. The largest section of each follicle (that is, through the centre) was stained (Feulgen stain) and used to assess the health status of the follicle (healthy: < five pycnotic bodies; atretic: > five pycnotic bodies) and to determine the number of granulosa cells. The latter was calculated from the mean cellular density (measured with a circular reticule) and the area occupied by granulosa cells (obtained as the difference 
between the total follicular area delineated by the basal membrane and the area of the antrum). The total number of granulosa cells per follicle was then obtained according to Gougeon (1981). The number of theca cells was not counted because of difficulties in defining the outside limit of the theca.

Granulosa cell differentiation index. Ki-67 is a nuclear antigen that is present during the G1, G2, S and M phases of the cell cycle, but absent in differentiated cells (Gerdes et al., 1984). $\mathrm{Ki}-67$ was used to determine the percentage of proliferating granulosa cells in each follicle and thereby the proportion of differentiated (non-proliferating) cells. Sections were heated in citrate buffer $\left(0.01 \mathrm{~mol} \mathrm{l}^{-1}, \mathrm{pH} 6.0\right)$ using a microwave oven

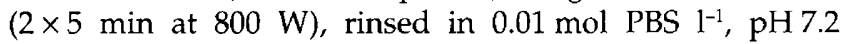
(Sigma) and immersed in $1.5 \%(\mathrm{v} / \mathrm{v})$ hydrogen peroxide in methanol. A prediluted monoclonal antibody (clone MIB-1; Immunotech, Marseille) was used and was applied overnight at $4^{\circ} \mathrm{C}$. An untreated section was used as a negative control for each follicle. The sections were then washed in PBS, incubated with a biotinylated secondary anti-mouse antibody and a streptavidine-biotin complex was revealed using diaminobenzidine as a chromogen (LSAB kit, DAKO, Trappes).

The number of labelled granulosa cells was counted and a differentiation index was calculated by dividing the number of non-labelled cells by the total number of granulosa cells. The number of differentiated cells was obtained by multiplying this index by the number of granulosa cells. This index was used to calculate steroid production per differentiated cell.

\section{Experiment 2: characterization of steroidogenic enzymes and two-dimensional protein patterns}

Animals. Thirteen ewes (six non-carriers and seven carriers) were used in this experiment, which was conducted at the same stage of the breeding season as in Expt 1. Procedures for the synchronization of oestrus and the scheduling of ovariectomy were as described for Expt 1.

Follicle handling. Large follicles ( $\geq 3 \mathrm{~mm}$ ) were dissected, measured and incubated individually for $1 \mathrm{~h}$ using the same protocol as in Expt 1. At the end of the incubation, the follicular fluid was collected from each follicle for a separate study. The follicular walls were then split into two. One half was immediately frozen in lysis medium $\left(10 \mathrm{mmol} \mathrm{KCl} \mathrm{l}^{-1}\right.$, $10 \mathrm{mmol}$ Tris $\mathrm{l}^{-1}, 0.5 \mathrm{mmol}$ EDTA $\mathrm{l}^{-1}$ ) containing protease inhibitors ( $1 \mathrm{mmol}$ phenyl methyl sulfonyl fluoride (PMSF) $\mathrm{l}^{-1}, 100 \mathrm{mmol} N$-tosyl-L-phenylalanine chloromethyl ketone (TPCK) $\mathrm{l}^{-1}$, and $100 \mathrm{mmol} N$ - $\alpha$-p-tosyl-L-lysine chloromethyl ketone (TLCK) $\mathrm{I}^{-1}$ ) and was used to study the concentrations of steroidogenic enzymes. The other half of the follicular wall was used to study neosynthesized proteins. The follicular walls were transferred to 24-well plates containing $1 \mathrm{ml}$ MEM supplemented with $1 \%$ polyvinyl alcohol (Sigma) and without methionine. ${ }^{35}$ [S]Methionine (NEN, Les Ulis; $50 \mathrm{mCi}$ per well) was then added and follicles were incubated for $20 \mathrm{~h}$ at $38^{\circ} \mathrm{C}$ in $95 \%$ air and $5 \% \mathrm{CO}_{2}$. At the end of the incubation, protease inhibitors (1 $1 \mu \mathrm{mol}$ PMSF $\mathrm{l}^{-1}, 100 \mu \mathrm{mol}$ TPCK $~^{-1}, 100 \mu \mathrm{mol}$ TLCK $1^{-1}$ ) were added to the follicular walls and the medium and these were collected and processed for electrophoresis.

One-dimensional electrophoresis and western blot analysis. The follicular walls retained for the determination of steroidogenic enzymes were subjected to sonication. The walls from each ewe were then pooled and their protein concentration was assessed (Bradford, 1976). Equal amounts of proteins were used for western blot analysis. The samples were heated for $1 \mathrm{~min}$ with electrophoresis sample buffer $\left(1.25 \mathrm{~mol}\right.$ Tris $\mathrm{l}^{-1}$ containing $15 \%(\mathrm{v} / \mathrm{v})$ glycerol, $10 \%(\mathrm{w} / \mathrm{v})$ SDS, $\mathrm{pH} 6.8)$ at $90^{\circ} \mathrm{C}$ and subjected to electrophoresis using $15 \mathrm{~cm} \times 13 \mathrm{~cm}$ polyacrylamide SDS gels (4\% stacking gels and 10\% separating gels). After electrophoresis, the proteins were transferred to a nitrocellulose membrane (Biorad, Ivrysur-Seine) by incubation overnight at $4^{\circ} \mathrm{C}$ in a buffer $(1.2 \%$ $(\mathrm{w} / \mathrm{v})$ glycine, $0.25 \%(\mathrm{w} / \mathrm{v})$ Tris, $20 \%(\mathrm{v} / \mathrm{v})$ methanol, $\mathrm{H}_{2} \mathrm{O}$ ). After transfer was completed, the quality of each blot was verified by staining the nitrocellulose with $0.2 \%(\mathrm{w} / \mathrm{v})$ Ponceau S stain (Sigma).

After transfer and staining, the membrane was washed with Tris buffered saline (TBS) $\left(10 \mathrm{mmol}\right.$ Tris $\mathrm{l}^{-1}$ containing $0.1 \%$ Tween 20, pH 7.4). The blot was incubated with blocking buffer ( $1 \mathrm{~mol}$ Tris $\mathrm{l}^{-1}$ with $5 \%(\mathrm{w} / \mathrm{v})$ milk powder, $0.2 \%(\mathrm{v} / \mathrm{v})$ Nonidet P-40, $\mathrm{pH} 7.4$ ) for $1 \mathrm{~h}$. The membrane was then incubated with primary antibodies in blocking buffer for $1.5 \mathrm{~h}$ at $37^{\circ} \mathrm{C}$ and subsequently washed with TBS. The primary antibodies were polyclonal rabbit sera anti-P450scc (Chicago University, Chicago, IL), anti-3 $\beta$-hydroxysteroid dehydrogenase (HSD) and anti-17 $\alpha$-hydroxylase (Royal Infirmary of Edinburgh NHS Trust) at a dilution of 1:1000. This was followed by incubation with peroxidase-labelled goat anti-rabbit antibody (Pasteur, Sanofi) at a dilution of 1:1000. Bands corresponding to the steroidogenic enzymes were visualized using chemiluminescence (Amersham, Les Ulis) and were quantified by densitometric analysis (Kepler Software, Large Scale Biology, Rockville, MD).

Two-dimensional electrophoresis. This procedure was used to compare the patterns of neosynthesized proteins in follicles of carriers with those in non-carriers. Both cellular and secreted proteins were studied. The amount of neosynthesized polypeptides in the culture medium was determined by measuring ${ }^{35}[S]$ methionine incorporation after extensive dialysis (cut off: $10 \mathrm{kDa}$ ) of the samples. Incorporation in cellular proteins was measured by scintillation spectrometry. Material from the ovulatory follicles of each ewe was pooled before electrophoresis. Twodimensional electrophoresis was performed as described by Roberts et al. (1984). Samples containing 200000 d.p.m. were dissolved in 1 mol urea $\mathrm{I}^{-1}$ containing $2 \%(\mathrm{v} / \mathrm{v})$ Nonidet P-40 and $0.5 \%(\mathrm{w} / \mathrm{v})$ dithiothreitol. Isoelectricfocusing was conducted in $4 \%$ polyacrylamide tube gels containing 250 $N N^{\prime}$ diallyltartramide, $8 \mathrm{~mol}$ urea $\mathrm{I}^{-1}, 2 \%(\mathrm{v} / \mathrm{v})$ Nonidet P-40 and 5.1\% (v/v) ampholytes, pH 3.5-10.0 (BDH, Poole).

Tube gels were equilibrated in $65 \mathrm{mmol}$ Tris- $\mathrm{HCl} \mathrm{l} \mathrm{l}^{-1}$, $\mathrm{pH} 6.8$, containing $1 \%(\mathrm{w} / \mathrm{v})$ SDS and $1 \%(\mathrm{v} / \mathrm{v}) \beta$-mercaptoethanol, and were then subjected to two-dimensional 
electrophoresis on polyacrylamide gels in the presence of $0.1 \%(\mathrm{w} / \mathrm{v})$ SDS.

Gels were then fixed in 30\% acetic acid, $10 \%$ ethanol and $\mathrm{H}_{2} \mathrm{O}$, and stained with Coomassie blue R250. The stain was removed with $10 \%$ ethanol and the gels were amplified with 1 mol sodium salicylate $\mathrm{l}^{-1}(30 \mathrm{~min})$ and dried. Radioactive proteins were detected by autoradiography on Kodak XOmat AR5 films after exposure for 3 weeks at $-80^{\circ} \mathrm{C}$.

Image analysis of the two-dimensional gels. For each genetic group and each type of sample (cellular or secreted), a general master pattern was obtained by co-migration of all the samples studied. This master contained all spots that were present at least once. The analysis was performed using the Kepler software (Large Scale Biology, Rockville, MD). Gels were digitized via a charge-coupled device camera (Kodak, Eikonix 1412) serving as scanner. Care was taken that saturation was not reached for any of the spots. Scanned gels were then processed for computer analysis using a Digital 3100 workstation. Spots were modelled as Gaussian least squares so that features of each pattern (position, intensity) were reduced in a spot file. The master gel was the reference enabling hand matching of individual spots from gel to gel. Finally, minor differences in overall load between gels (as defined by the sum of the darkness of all spots) were corrected to produce accurate measurements of spot intensity in the gels.

\section{Statistical analysis}

Statistical analysis of steroid production and data on follicle size, number of granulosa cells and differentiation index were conducted using the general linear method (GLM) procedure of SAS. For each steroid, the model had effects for genetic group (carrier or non-carrier) and ewe within group. The significance of effects for group was tested against the mean squares for ewes within group. The data on steroid production were also analysed using this model augmented with follicle size as a covariate. Analysis of the two-dimensional PAGE was conducted by chi-square (frequency of the presence of a spot) or $t$ test (quantitative differences). All results are given as least squares means $\pm \mathrm{SE}$.

\section{Results}

\section{Ovulation rate and number of follicles}

The distribution of ovulation rates of the experimental ewes (Expts 1 and 2 pooled) before the study are shown (Fig. 1). The mean ovulation rate of the carrier group was $5.5 \pm 0.6$ compared with a mean of $2.3 \pm 0.1$ for the noncarriers $(P<0.001)$. Moreover, one carrier ewe (ewe 21) had a mean lifetime ovulation rate of 11.3 (8-15 ovulations).

The number of ovulatory follicles per ewe for the cycle under study may be determined using morphological (large and healthy, as evidenced by the absence of pycnotic bodies) or functional (producing more than a specified amount of oestradiol) criteria. Follicles in Expt $1(n=42)$ were used to compare these two criteria to verify whether the oestradiol

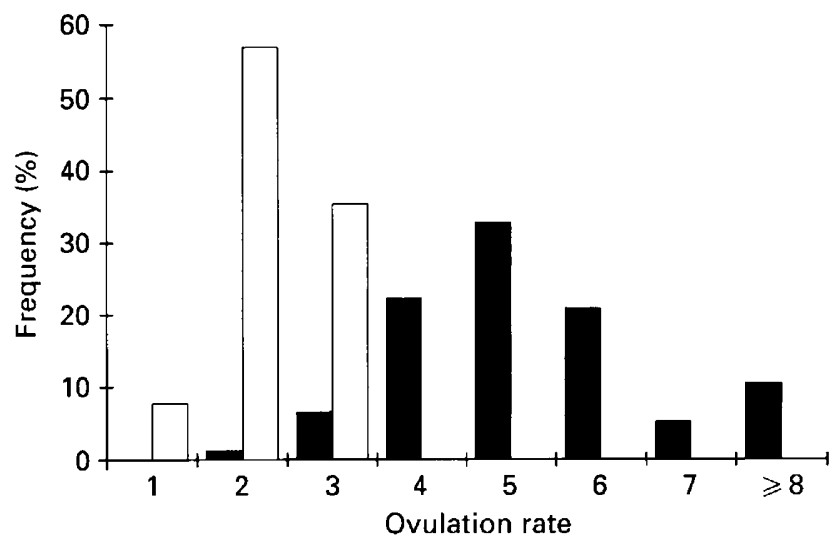

Fig. 1. Frequency distribution (\%) of lifetime observations on ovulation rate of Belclare ewes classified as $(\square)$ carriers or $(\square)$ noncarriers of a major gene that affects ovulation rate.

threshold of $500 \mathrm{pg} \mathrm{ml}^{-1} \mathrm{~h}^{-1}$ defined by Webb et al. (1989) was valid for Belclare follicles. The use of this threshold resulted in the misclassification of three healthy follicles that had oestradiol secretion rates between 250 and $500 \mathrm{pg} \mathrm{m}^{-1} \mathrm{~h}^{-1}$. When a threshold of $250 \mathrm{pg} \mathrm{ml}^{-1} \mathrm{~h}^{-1}$ was used, all healthy follicles produced concentrations of oestradiol in excess of this threshold, and only two atretic follicles were misclassified. Hence, follicles that produced oestradiol at a rate $>250 \mathrm{pg} \mathrm{ml}^{-1} \mathrm{~h}^{-1}$ were designated as 'ovulatory follicles'.

In Expt 1, 14 large follicles were dissected for non-carriers and ten of these were ovulatory. Carrier ewes yielded 28 follicles and 25 of them were ovulatory. In Expt 2, 12 follicles were obtained from non-carriers and all of them were ovulatory, while 34 of 36 follicles dissected from carriers were classified as ovulatory. The proportion of nonovulatory follicles (averaged for Expts 1 and 2) did not differ significantly between the groups (carriers $8 \%$, non-carriers $15 \%$ ).

The combined results from Expts 1 and 2 showed that the average number of ovulatory follicles was greater in carriers than in non-carriers $(4.9 \pm 0.4$ versus $2.0 \pm 0.2, P<0.001)$ and reflected the differences in ovulation rate before the study. Follicles from carriers were significantly smaller in diameter $(4.4 \pm 0.1 \mathrm{~mm}$ versus $5.7 \pm 0.2 \mathrm{~mm}, P<0.001)$. The carrier ewe with the highest lifetime ovulation rate (ewe 21) yielded eight ovulatory follicles and the mean diameter was $3.3 \pm$ $0.3 \mathrm{~mm}$.

\section{Steroid secretion (Expts 1 and 2 pooled)}

Least squares means for the oestradiol secretion of ovulatory follicles were $3.7 \pm 0.9$ and $2.4 \pm 0.6 \mathrm{ng} \mathrm{ml}^{-1} \mathrm{~h}^{-1}$ for non-carriers and carriers, respectively. Large variation between ewes and among follicles within ewes were detected (Fig. 2). When the statistical model used for analysis incorporated effects for carrier group and the ewe within group, only the latter was significant $(P<0.001)$. Furthermore, when follicle size was included in the model as a covariate, the regression of oestradiol secretion on follicle 


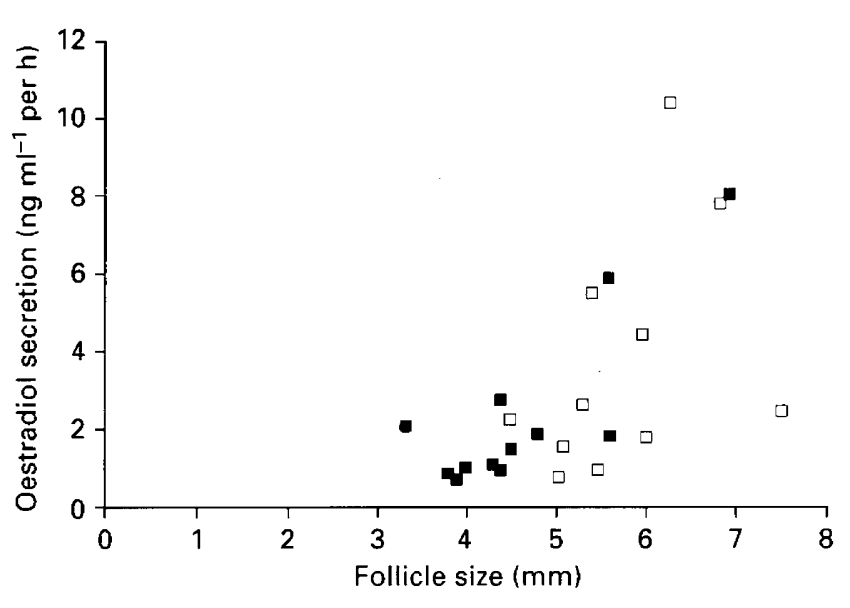

Fig. 2. Relationships between follicle size and mean in vitro oestradiol secretion per ewe (averaged over all ovulatory follicles from each ewe) in Belclare ewes classified as ( $\square$ ) carriers or ( $\square$ ) noncarriers of a major gene that affects ovulation rate.

size did not depend on genetic group. Hence, it was concluded that oestradiol secretion was not affected by carrier status.

Least squares means for progesterone secretion were similar for follicles from non-carriers $\left(1.1 \pm 0.2 \mathrm{ng} \mathrm{ml}^{-1} \mathrm{~h}^{-1}\right)$ and carriers $\left(0.6 \pm 0.1 \mathrm{ng} \mathrm{ml}^{-1} \mathrm{~h}^{-1}\right)$. The analysis detected significant effects of follicle size $(P<0.05)$, but not for carrier status (regardless of whether follicle size was included in the model).

Mean values of in vitro testosterone production per ewe ranged from 0.4 to $2.7 \mathrm{ng} \mathrm{m}^{-1} \mathrm{~h}^{-1}$ for the follicles from noncarriers compared with 0.1 to $1.8 \mathrm{ng} \mathrm{ml}^{-1} \mathrm{~h}^{-1}$ for follicles from carriers. Seven of 11 non-carrier ewes had values in the range $0.4-0.7 \mathrm{ng} \mathrm{ml}^{-1} \mathrm{~h}^{-1}$ and the remainder had values $>0.7 \mathrm{ng}$ $\mathrm{ml}^{-1} \mathbf{h}^{-1}$. In the carrier ewes, testosterone production was in the range $0.4-0.7 \mathrm{ng} \mathrm{ml}^{-1} \mathrm{~h}^{-1}$ in 6 of 12 animals, $<0.4 \mathrm{ng} \mathrm{ml}^{-1}$ $\mathrm{h}^{-1}$ in four animals and $>0.7 \mathrm{ng} \mathrm{ml}^{-1} \mathrm{~h}^{-1}$ in one animal. Least squares means for testosterone secretion were $1.9 \pm 0.4$ and $1.4 \pm 0.3 \mathrm{ng} \mathrm{ml}^{-1} \mathrm{~h}^{-1}$ for follicles from non-carriers and carriers, respectively. The $F$ test for differences between the groups did not reach significance, regardless of whether follicle size was included in the statistical model.

Overall, these results show that the ability of follicles from carrier ewes to produce steroids was only marginally reduced compared with follicles from non-carriers.

\section{Experiment 1: granulosa cell number and differentiation index}

Number of granulosa cells in ovulatory follicles. Ten follicles from non-carrier ewes and 25 from carrier ewes were examined. The mean number of granulosa cells per follicle was significantly greater for the non-carrier group $(988000 \pm$ 87000 versus $625000 \pm 45000, P<0.001)$. The regressions linking follicle size $(x)$ and number of granulosa cells $(y)$ were $y=422764 x-573706, r=0.73, P<0.01$, and $y=309778 x$ - 78236, $r=0.81, P<0.01$, for carriers and non-carriers, respectively.
Cell differentiation index. Ovulatory follicles from noncarriers and carriers contained similar proportions of differentiated granulosa cells $(39.6 \pm 12.3 \%$ versus $36.3 \pm$ $6.4 \%$, respectively). For each follicle, the total number of differentiated cells was calculated from the total number of cells and from the fraction that was differentiated. The number of differentiated granulosa cells was greater in follicles from non-carriers $(394000 \pm 140000)$ than in follicles from carriers $(218000 \pm 39000, P=0.05)$.

The mean oestradiol secretion per differentiated granulosa cell was obtained by dividing oestradiol secretion per follicle by the number of differentiated cells. The results were similar for non-carriers and carriers $\left(55 \times 10^{-3} \pm 30.2 \times\right.$ $10^{-3} \mathrm{pg} \mathrm{ml}^{-1} \mathrm{~h}^{-1} \quad$ versus $58 \times 10^{-3} \pm 18.9 \times 10^{-3} \mathrm{pg} \mathrm{ml}^{-1} \mathrm{~h}^{-1}$, respectively). This result demonstrates that the ability of each granulosa cell to produce oestradiol was not affected by carrier status and that the lower oestradiol secretion of follicles from carrier ewes was a direct consequence of the reduced number of granulosa cells.

\section{Experiment 2: steroidogenic enzymes and two-dimensional patterns of secreted and cellular proteins}

Steroidogenic enzymes. The ovulatory follicles of each ewe (six non-carriers and seven carriers) were pooled. Equal amounts of protein of pooled follicular walls were subjected to one-dimensional PAGE. P450scc, $17 \alpha$-hydroxylase and $3 \beta$ HSD were visualized in the samples of cellular proteins at 50 , 53 and $48 \mathrm{kDa}$, respectively. A representative blot probed with an antibody raised against P450scc is shown (Fig. 3). Densitometric analysis of the bands obtained after western blot analysis failed to detect any difference between the groups for P450scc (96500 \pm 6100 versus $78800 \pm 7900$ ), $17 \alpha-$ hydroxylase $(42400 \pm 5500$ versus $33400 \pm 8900)$ or $3 \beta-\mathrm{HSD}$ $(10300 \pm 3300$ versus $17100 \pm 3400)$ (values are arbitrary units for non-carriers versus carriers, respectively). Positive correlations between the P450scc signal and in vitro progesterone secretion were found for follicles from noncarriers $(r=0.8, n=6, P=0.05)$ and for carriers $(r=0.89, n=7$, $P<0.01)$. The correlation between $3 \beta$-HSD and progesterone secretion was positive $(r=0.21$ and 0.53 for non-carriers and carriers, respectively) but did not reach statistical significance in either group. A similar result was found for the correlation between $17 \alpha$-hydroxylase and testosterone secretion $(r=0.28$ and 0.33 for non-carriers and carriers, respectively).

Two-dimensional electrophoretic analysis of cellular proteins. Follicular walls from each ewe were pooled to characterize the cellular proteins and to compare the two groups by twodimensional PAGE and image analysis. Two-dimensional patterns of all ewes were generated but only those from seven carriers and five non-carriers were of the high quality required for image analysis. The experimental conditions (concentrations of acrylamide and ampholytes) for twodimensional PAGE enabled visualization of proteins between 20 and $100 \mathrm{kDa}$ with an isoelectric point ranging from 4.5 to 7.6 . 


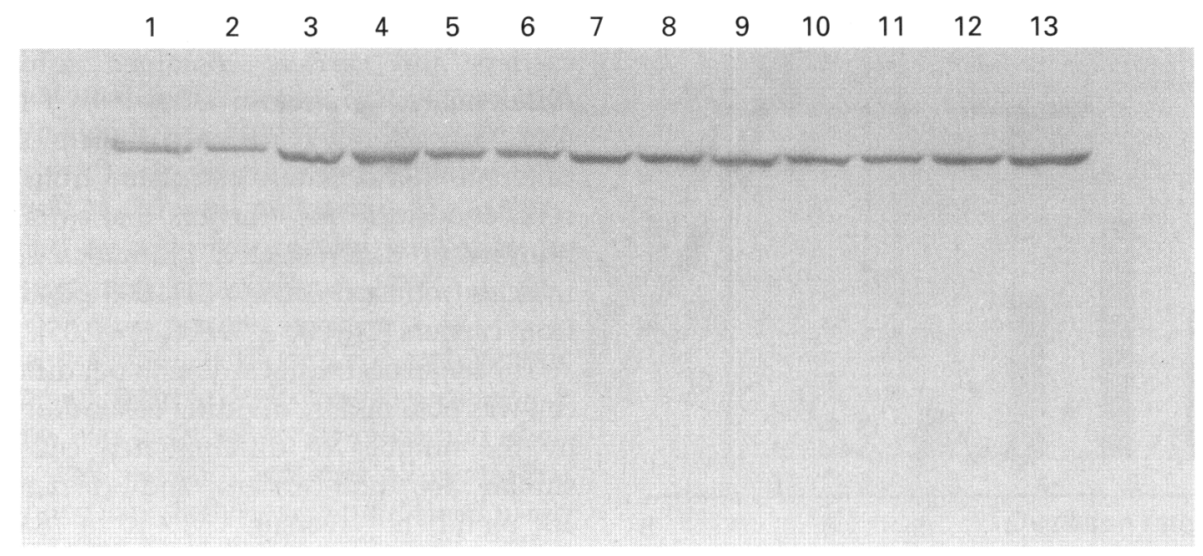

Fig. 3. Representative western blot showing the detection of a signal at $50 \mathrm{kDa}$ in cellular proteins of follicular walls from Belclare ewes classified as carriers $(n=7$, lanes $1-7)$ or noncarriers ( $n=6$, lanes $8-13$ ) of a major gene that affects ovulation rate, after probing the blot with an antibody raised against $P 450$ scc.

Representative patterns are presented for carrier and noncarrier ewes (Fig. 4a,b). A total of 138 spots was visualized on the master pattern (Fig. 4c). Examination of qualitative variations revealed that only two spots differed significantly between the groups $(P<0.01)$. These were spot 26 and spot 47 , which were observed in five of seven carriers (spot 47 was absent from the pattern for ewe 21), but were absent from all the non-carriers. Spot 26 and spot 47 had molecular masses and isoelectric points of $78 \mathrm{kDa}$ and pI 5.6 and $49 \mathrm{kDa}$ and pI 5.8, respectively. These spots are minor proteins and only represent $2.5 \%$ (spot 26 ) and $1.6 \%$ (spot 47 ) of the total radioactivity. They could not be stained with Coomassie blue.

Quantitative differences between the two groups were found to be significant for three spots (spots 5, 8 and 50). Spot 5 had a molecular mass of $76 \mathrm{kDa}$ (pI 5.8) and was reduced in the patterns from non-carriers $(129200 \pm 9800$ units in carriers versus $52700 \pm 12300$ units in non-carriers; $P<0.01$ ), as was spot $8(60 \mathrm{kDa}$, pI $5.5 ; 165500 \pm 17400$ units in carriers versus $113900 \pm 8100$ units in non-carriers; $P<0.05)$. In contrast, spot $50(38 \mathrm{kDa}, \mathrm{pI} 6.8)$ was more abundant in the patterns from non-carrier ewes $(38300 \pm 6500$ units versus $69300 \pm 12600$ units; $P<0.05$ ). These spots were not stained by Coomassie blue.

Two-dimensional electrophoretic analysis of secreted proteins. Media from the ovulatory follicles from each ewe were pooled before electrophoresis. Seven carrier ewes and five non-carrier ewes yielded two-dimensional patterns with a quality that was suitable for image analysis. Representative fluorographs from carriers and non-carriers are presented (Fig. $5 a, b$ ). In addition, the master gel and the differences between the groups that were detected by image analysis are shown (Fig. 5c).

Under the electrophoresis conditions used, 218 spots were identified on the master pattern. Of these, 170 and 144 were present at least once in carrier and non-carrier patterns, respectively. Examination of qualitative variations between the groups showed that five spots were affected: spots 77 (53 kDa, pI 5.3) and 155 (41 kDa, pI 5.7) were present in four of seven carrier patterns but were absent from all non-carrier patterns $(P<0.01)$. Spot 209 (45 kDa, pI 6.3), spot 210 (97 kDa, pI 7.9) and spot $218(91 \mathrm{kDa}, \mathrm{pI} 7.5)$ were absent from the patterns for carriers but were visible in four of five noncarrier patterns $(P<0.01)$.

Examination of quantitative variations identified differences regarding two spots. The presence of spot 51 $(88 \mathrm{kDa}, \mathrm{pI} 5.5)$ was unaffected by genotype (four of seven carriers and five of five non-carriers), but the amount was reduced in the media from carriers $(43000 \pm 20200$ units versus $108000 \pm 20500$ units, $P<0.05)$. Spot $109(31 \mathrm{kDa}$, pI 6.3) was present in five of seven carriers and four of five non-carriers but quantitative differences were evident (101000 \pm 36400 units for carriers versus $241000 \pm 65100$ units for non-carriers; $P<0.05$ ).

Thus, two secreted proteins (spots 77 and 155) appear to be typical of follicles from carrier ewes, while three proteins (spots 209, 210 and 218) appear to be typical of follicles from non-carrier ewes. Furthermore, follicles from carrier ewes secreted reduced amounts of the proteins represented by spots 51 and 109 .

\section{Discussion}

The aim of this study was to compare morphological and functional features of follicles from two groups of ewes representing non-carriers and carriers of a gene that has a large effect on ovulation rate. Because the sires of the experimental ewes were also carriers of an autosomal gene causing ovarian hypoplasia, which is not identical to the major gene for ovulation rate, it is likely that the carriers and non-carriers differ at two loci with major effects on ovarian function. Although this complicates interpretation of the results, it also presents new possibilities for the identification of intraovarian factors controlling ovarian function. 
(a)

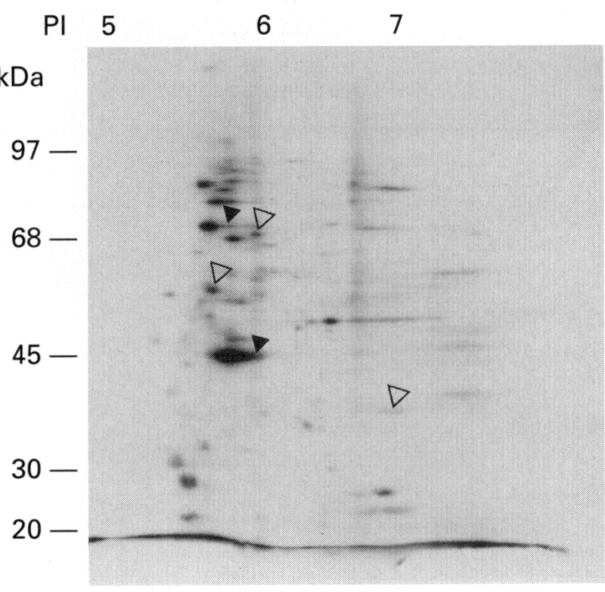

(b)

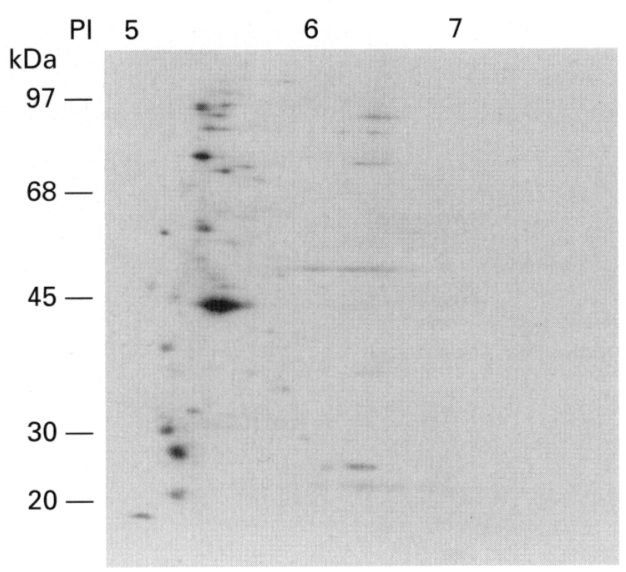

(c)

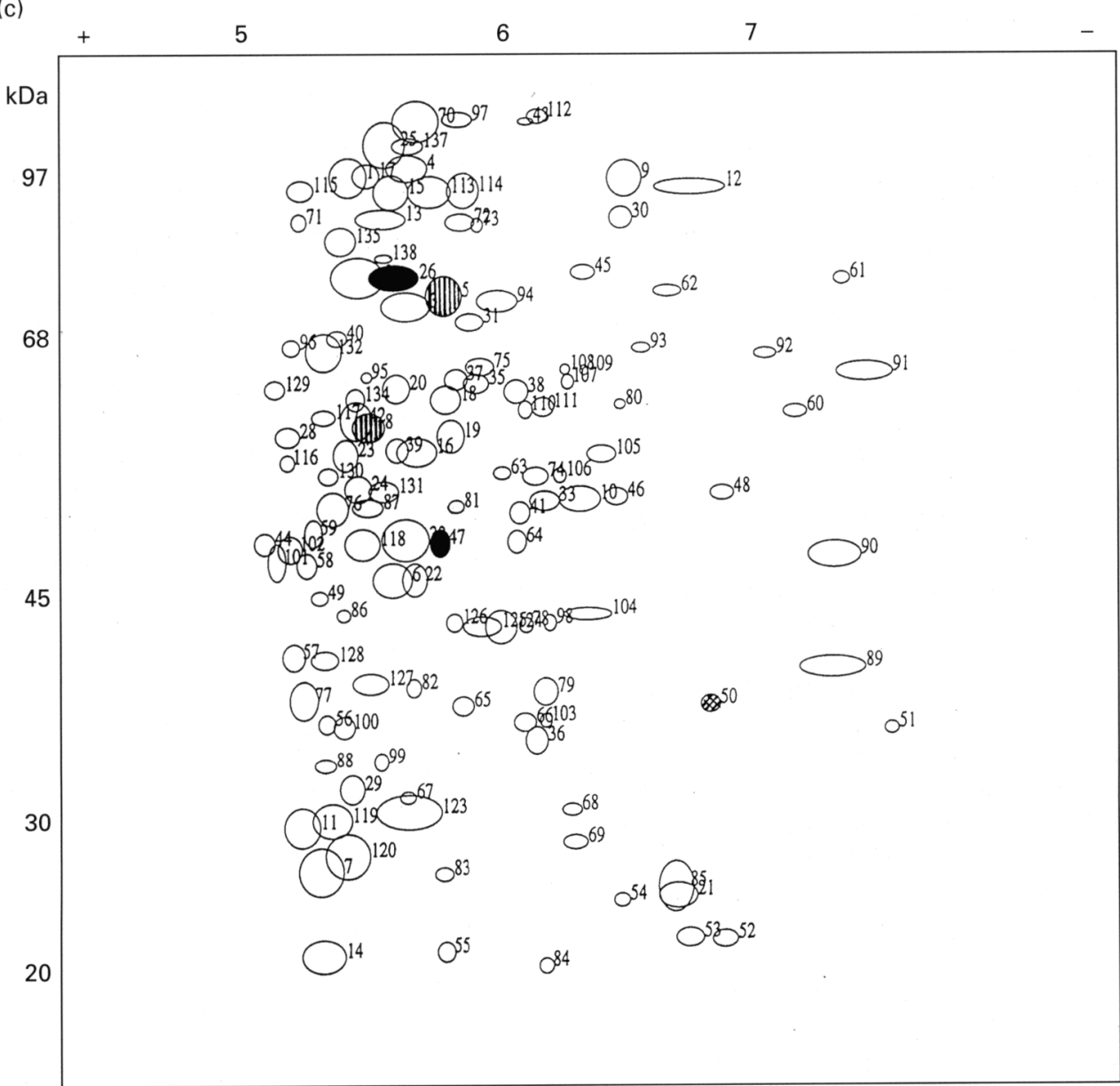

Fig. 4. Representative fluorographs of cellular proteins of follicular walls of individual Belclare ewes classified as (a) a carrier and (b) a non-carrier of a major gene that affects ovulation rate (ovulatory follicles of each ewe were pooled). Qualitative differences are indicated by solid arrowheads; quantitative differences are shown by open arrowheads. (c) Master gei summarizing the total number of spots detected among cellular proteins of follicular walls. Qualitative differences are shown as (always absent in Belclare non-carrier patterns). Quantitative differences are also shown $(\mathbb{1}$, carrier $>$ non-carrier; $\otimes$, non-carrier $>$ carrier). Molecular mass markers are indicated on the left and the charge separation produced by isoelectrofocusing is shown at the top of the figure. 
(a)

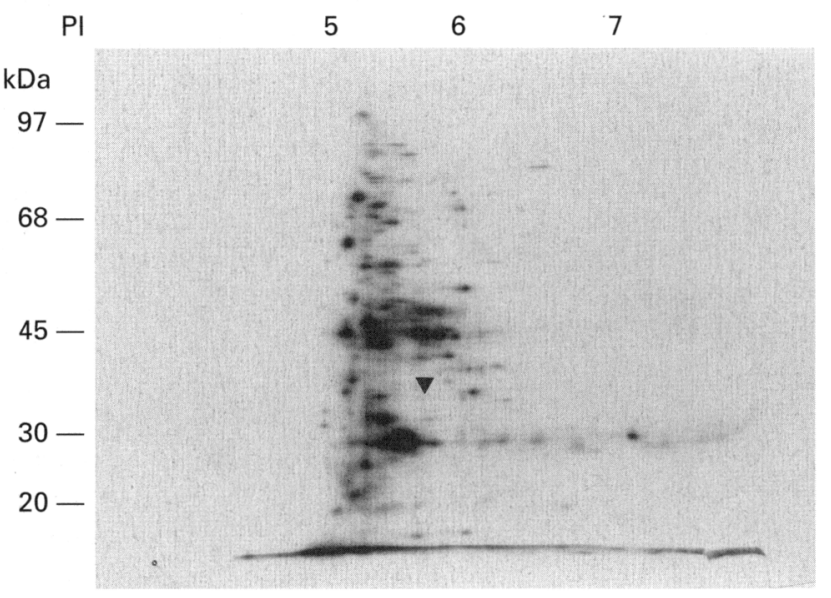

(b)

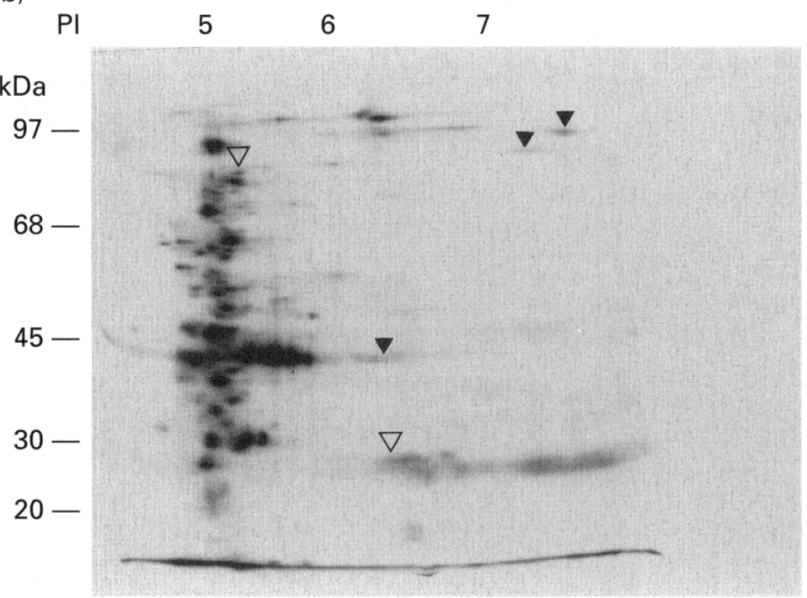

(c)

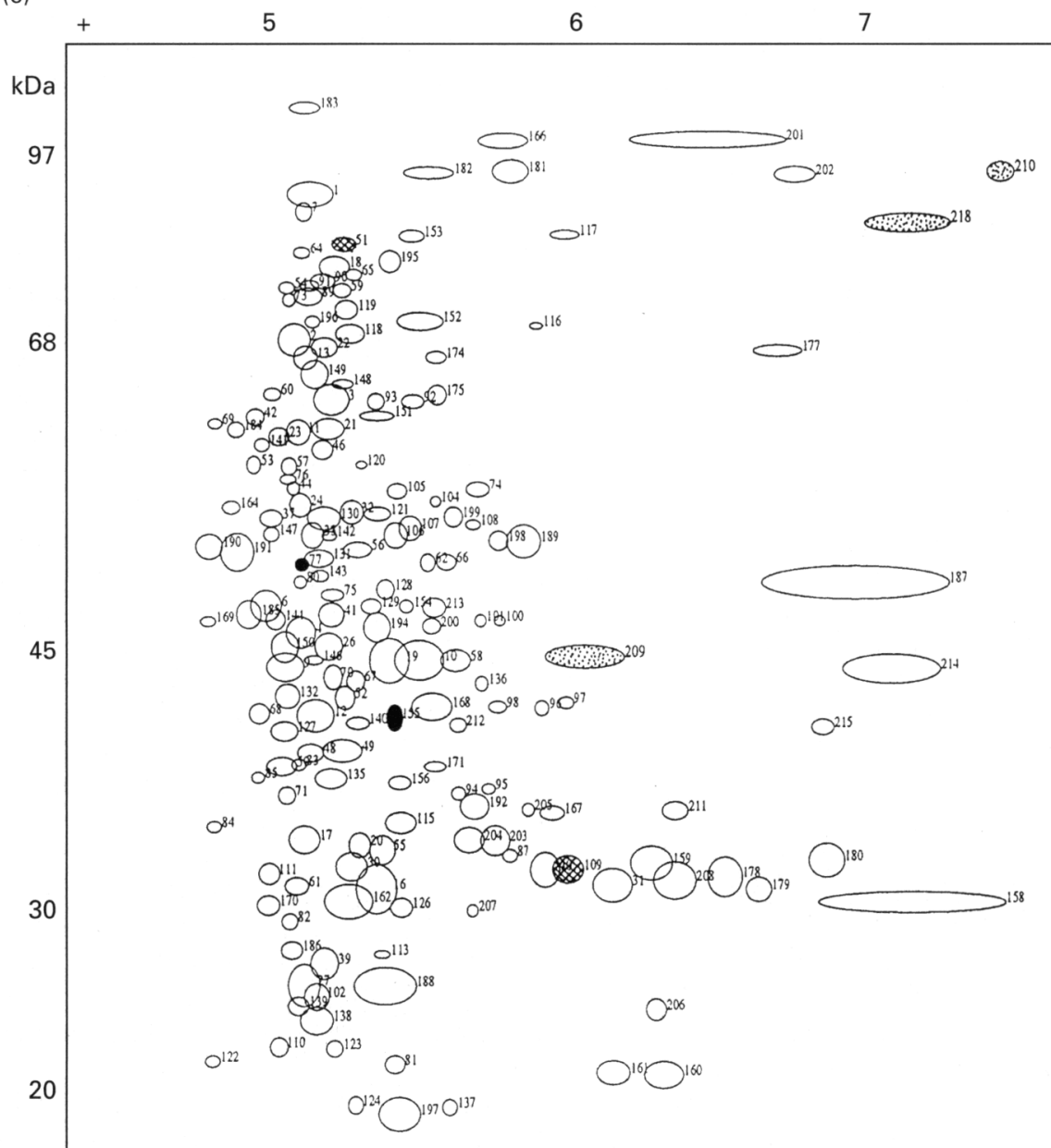

Fig. 5. Representative fluorographs of secreted proteins of follicular walls of individual Belclare ewes classified as (a) a carrier and (b) a noncarrier of a major gene that affects ovulation rate (ovulatory follicles of each ewe were pooled). Note that spot 77 was not present in the carrier ewe. Qualitative differences are indicated by solid arrowheads; quantitative differences are shown by open arrowheads. (c) Master gel summarizing the total number of spots detected among secreted proteins. Qualitative differences are shown as (always absent from Belclare carrier patterns) and (always absent from Belclare non-carrier patterns). Quantitative differences are also shown ( non-carrier $>$ carrier). Molecular mass markers are indicated on the left and the charge separation produced by isoelectrofocusing is shown at the top of the figure. 
Donovan and Hanrahan (1993) reported that the timing of periovulatory events in Belclare carriers and non-carriers was similar. Therefore, the intervals between the induction of luteal regression and the onset of oestrus and subsequent interval to the preovulatory $\mathrm{LH}$ surge were unaffected by

-rier status (Donovan and Hanrahan, 1993; Hanrahan, 1994). Hence, it can be argued that in the present study, the ovulatory follicles were all harvested at equivalent stages relative to ovulation and were equally mature.

Morphological analysis demonstrated that follicles from Belclare carriers were smaller than those from non-carriers and contained fewer granulosa cells. These features were also described for Booroola and Inverdale ovulatory follicles (McNatty et al., 1986; Shackell et al., 1993). The mechanisms that induce these alterations in the Belclare follicles remain unknown; the Belclare genes may trigger an alteration in size-related changes in granulosa cell proliferation, as reported in Booroola (Driancourt et al., 1985). It is not known whether these changes are produced by a change in the oocyte-granulosa relationship (Vanderhyden et al., 1993), or by an alteration in the pattern of granulosa cell differentiation resulting in an earlier decrease in proliferation. In each genetic group, characterization of the changes in terms of the percentage of $\mathrm{Ki}-67$ negative cells within follicles of different sizes would help to clarify which of these two hypotheses is valid. In ovulatory follicles, granulosa cells of follicles from carriers and non-carriers had a similar differentiation index (average $40 \%$ ). This index has not been estimated in Booroola or Inverdale follicles, but appears to be lower than that observed in granulosa cells originating from large antral follicles from Romanov ewes and cultured in vitro (Monniaux et al., 1994).

In other prolific breeds, the concentration of steroids in follicular fluid and the aromatase activity of granulosa cells in vitro are the markers used most often to characterize follicular function (McNatty et al., 1986; Shackell et al., 1993). In the present study, this range of parameters was extended to quantify the steroidogenic ability of each follicle as measured by (i) the amount of steroidogenic enzymes present in the follicular wall and (ii) the steroid secretion per differentiated granulosa cell.

In each follicle in which the number of granulosa cells and in vitro oestradiol secretion were measured, the oestradiol secretion, when expressed per differentiated granulosa cell, was similar between genetic groups. The finding that ewes carrying the $F e c^{\mathrm{B}}$ allele have the same ovarian secretion rate of oestradiol as ewes not carrying Fec ${ }^{\mathrm{B}}$ (McNatty et al., 1987) indicates that the same is true for the Booroola gene.

There was no effect of carrier status on the amount of testosterone produced per follicle or on the amount of $17 \alpha$ hydroxylase per milligram of follicular wall. However, this production could not be expressed per theca cell due to the inability to estimate the number of theca cells. The evidence for the similarity of function of theca cells in the two groups is in agreement with other reports on $\mathrm{Fec}^{\mathrm{B}}$ carriers and noncarriers (McNatty et al., 1986).

Owing to the fact that there are no differences in FSH concentrations in Belclare carrier and non-carrier ewes (Hanrahan, 1997), it was hypothesized that alteration in local ovarian mechanisms may cause the high ovulation rate of carrier ewes. Two types of compounds, growth factors or proteins, may be involved. Numerous growth factors, such as insulin-like growth factors (Monget and Monniaux, 1995), transforming growth factor $\beta$ (TGF $\beta$; Gitay-Goren et al., 1993), epidermal growth factor (EGF; Hsuch et al., 1981), and fibroblast growth factor (FGF; Spicer and Stewart, 1996), have the potential to affect positively or negatively gonadotrophin action on ovarian cells. Alternatively, cellular (for example, FSH receptor) or secreted (activin and inhibin; Miro and Hillier, 1992) ovarian proteins may also affect gonadotrophin action on ovarian cells. There was no obvious candidate to explain the genetic differences in follicular size and numbers, thus a procedure was undertaken that resolves all follicular proteins and some high molecular weight growth factors such as FGF. The procedure was based on two-dimensional electrophoresis, since two-dimensional PAGE was useful in identifying markers of major genes or mutations (Aquadro and Avise, 1981; Bossis and Mugniery, 1993; Gormon and Phan Than, 1995). This procedure, combined with image analysis, was applied to the analysis of cellular and secreted proteins of carrier and non-carrier ewes.

A total of 218 secreted proteins were identified in the culture medium of the follicles from Belclare ewes. The general features of the Belclare master gel were similar to those obtained for Booroola ewes (Driancourt et al., 1996). Most of the proteins had isoelectric points ranging between 5 and 7. In both breeds (Booroola and Belclare), major spots could be identified at 30 and $45 \mathrm{kDa}$. However, a strict comparison between the spots in Belclare and Booroola samples could not be attempted because the master gels were different. When differences between the patterns of Belclare carriers and non-carriers were analysed, seven spots of interest were identified. Two of these corresponded to spots that were specific to follicles from carrier ewes. Whether these are real genetic differences or are caused by the size differences between the follicles is not clear. However, in $\mathrm{Fec}^{\mathrm{B}}$ carriers, size affected a small number of spots (Driancourt et al., 1996) and the physicochemical features of spots 77 and 155 do not correspond to those of the size-related spots in the earlier study (Driancourt et al., 1996). Five other spots showed differences $(209,210,218,51$ and 109). Interestingly, spot 218 in the Belclare non-carrier patterns has identical physicochemical features to spot 129 of $\mathrm{Fec}^{+} \mathrm{Fec}^{+}$patterns. The absence of this spot when the Belclare or $\mathrm{Fec}^{\mathrm{B}}$ genes are present indicates a common genetic mechanism. All other spots associated with carrier status in the Belclare breed were not found to be affected by genotype in the Booroola study (Driancourt et al., 1996).

Two-dimensional PAGE on lysates of follicular walls was undertaken to characterize cellular proteins, and 138 spots were detected on the master pattern. This is the first study to describe cellular proteins of ovine ovarian follicles. In agreement with Savion and Gospodarowicz (1980), who described proteins of bovine granulosa cells, the major spot appeared at $45 \mathrm{kDa}$ and may be actin. However, the differences in the culture procedures used in these two studies (long-term culture of bovine granulosa cells compared with short-term culture of follicular walls) prevented further comparison between the species. Two 
interesting spots were identified that were always absent in Belclare non-carrier patterns (spots 26 and 47). Both spots appear to be specific for the Belclare genotype, as they were not variable in another genetic model: lines of Finn sheep that differed because of divergent selection on ovulation rate (K. Reynaud, J. P. Hanrahan and M. A. Driancourt, unpublished). The observation that the molecular weight of spot 26 is close to that of one of the forms of the FSH receptor is noteworthy (Vannier et al., 1996).

In conclusion, morphological and functional features of Belclare follicles were similar to those described for Booroola follicles (McNatty et al., 1986). In addition, one spot among the secreted proteins is similarly altered in Belclare and $\mathrm{Fec}^{\mathrm{B}}$ gene carriers, although its identity remains to be established. Investigation of whether molecular markers of the $\mathrm{Fec}^{\mathrm{B}}$ gene (Lanneluc et al., 1994; Montgomery et al., 1994) are also operative in Belclare ewes would help to extend these results. The fact that the presence of a number of other proteins depends on carrier status is consistent with the hypothesis that at least two loci with large effects on ovarian function are segregating in Belclare sheep. Further studies, at both the physiological and genetic levels, are required to understand fully the major genetic effects on ovulation rate in this sheep population.

This research was funded by an EC/AIR contract No. 920232. Provision of $\mathrm{P} 450 \mathrm{scc}$ antibody by B. Hales, Chicago University, Chicago, IL, USA, and of the $3 \beta-\mathrm{HSD}$ and $17 \alpha$-hydroxylase antibodies by I. J. Mason, Royal Infirmary of Edinburgh NHS Trust, Edinburgh, Scotland, is gratefully acknowledged.

\section{References}

Aquadro CF and Avise JC (1981) Genetic divergence between rodent species assessed by two dimensional electrophoresis Proceedings National Academy of Sciences USA 78 3784-3788

Bossis M and Mugniery D (1993) Specific status of six Globodera parasites of solanaceous plants studied by means of two dimensional gel electrophoresis with a comparison of gel patterns by a computed system Fundamental and Applied Nematology 16 47-56

Bradford MM (1976) A rapid sensitive method for the quantitative analysis of microgram quantities of protein utilising the principle of protein-dye binding Annals of Biochemistry 72 248-254

Davis GH, Montgomery GW, Allison AJ, Kelly RW and Bray AR (1982) Segregation of a major gene influencing fecundity in progeny of Booroola sheep New Zealand Journal of Agricultural Research 25 525-529

Davis GH, McEwan JC, Fennessy PF, Dodds KG and Farquhar PA (1991) Evidence for the presence of a major gene influencing ovulation rate on the X chromosome of sheep Biology of Reproduction $44620-624$

Davis GH, McEwan JC, Fennessy PF, Dodds KG, McNatty KP and O WS (1992) Infertility due to bilateral ovarian hypoplasia in sheep homozygous $\left(F e c X^{\prime} F e c X^{\prime}\right.$ ) for the Inverdale prolificacy gene located on the $X$ chromosome Biology of Reproduction $46636-640$

Donovan A and Hanrahan JP (1993) Onset and duration of oestrus and plasma oestradiol and FSH levels in Cambridge, Belclare and Finn ewes: relationship with ovulation rate Irish Journal of Agricultural and Food Research 32112

Driancourt MA, Cahill LP and Bindon BM (1985) Ovarian follicular populations and preovulatory enlargement in Booroola and control Merino ewes Journal of Reproduction and Fertility 73 93-107

Driancourt MA, Gormon T, Phan Than L and Boomarov O (1996) Analysis of proteins secreted by sheep ovarian follicles by two dimensional electrophoresis: effects of the $\mathrm{Fec}^{\mathrm{B}}$ gene, follicle size and atresia Journal of Reproduction and Fertility $10769-77$

Elsen JM and Le Roy P (1990) Detection of major genes and determination of genotypes. Application to discrete variables Proceedings of $4^{\text {th }}$ World Congress on Genetics Applied to Livestock Production 1537-49

Fry RC, Clarke IJ, Cummins JT, Bindon BM, Piper LR and Cahill LP (1988) Induction of ovulation in chronically hypophysectomised Booroola ewes Journal of Reproduction and Fertility 82 711-715

Gerdes J, Lemke H, Baisch H, Wacker HH, Schwab U and Stein H (1984) Cell cycle analysis of a cell proliferation-associated human nuclear antigen defined by the monoclonal antibody Ki-67 Journal of Immunology 133 1710-1715

Gitay-Goren H, Kim I-C, Miggans ST and Schomberg DW (1993) Transforming growth factor-beta modulates gonadotropin receptor expression in porcine and rat granulosa cells differently Biology of Reproduction 48 1284-1289

Gormon T and Phan Than L (1995) Identification and classification of Listeria by two dimensional protein mapping Research in Microbiology 146 143-154

Gougeon A (1981) Cinétique de la croissance et de l'involution des follicules ovariens pendant le cycle menstruel chez la femme Dr Sc. Thesis, Paris

Hanrahan JP (1990) Single gene effects on ovulation rate in the Cambridge and Belclare breeds. In Major Genes for Reproduction in Sheep pp 93-102 Eds JM Elsen, L Bodin and J Thimonier. INRA Editions, Paris

Hanrahan JP (1994) Annual Report of EC/AIR Contract No. 920232

Hanrahan JP (1997) Annual Report of EC/AIR Contract No. 920232

Hochereau-de Reviers MT, Copin M, Seck M, Monet-Kuntz C, Cornu C, Fontaine I, Perreau C, Elsen JM and Boomarov O (1990) Stimulation of testosterone production by PMSG injection in the ovine male: effect of breed and age and application to males carrying or not carrying the F Booroola gene Animal Reproduction Science 23 21-30

Hsuch AJW, Walsh TH and Jones PBC (1981) Inhibition of ovarian and testicular steroidogenesis by epidermal growth factor Endocrinology 108 2002-2004

Lanneluc I, Drinkwater RD, Elsen JM, Hetzel DJ, Nguyen TC, Piper LR, Thimonier J, Harrison B and Gellin J (1994) Genetics markers for Booroola fecundity ( $F e c$ ) gene in sheep Mammalian Genome 5 26-33

McNatty KP, Lun S, Heath DA, Ball K, Smith P, Hudson NL, McDiarmid J, Gibb M and Henderson KM (1986) Differences in ovarian activity between Booroola $\times$ Merino ewes which were homozygous, heterozygous and non-carriers of a major gene influencing their ovulation rate Journal of Reproduction and Fertility 77 193-205

McNatty KP, Hudson N, Henderson KM, Gibb M, Morrison L, Ball K and Smith $\mathbf{P}$ (1987) Differences in gonadotrophin concentrations and pituitary responsiveness to $\mathrm{GnRH}$ between Booroola ewes which were homozygous $(\mathrm{FF})$, heterozygous $\left(\mathrm{F}^{+}\right)$and non-carriers $(++)$of a major gene influencing their ovulation rate lournal of Reproduction and Fertility 80 577-588

Miro F and Hillier SG (1992) Relative effects of activin and inhibin on steroid hormone synthesis in primate granulosa cells Journal of Clinicat Endocrinology and Metabolism 75 1556-1561

Monget P and Monniaux D (1995) Growth factors and the control of folliculogenesis Journal of Reproduction and Fertility Supplement 49321-333

Monniaux D, Pisselet C and Fontaine J (1994) Uncoupling between proliferation and differentiation of ovine granulosa cells in vitro. Journal of Endocrinology 142 497-510

Montgomery GW, Lord EA, Penty JM, Dodds KG, Broad TE, Cambridge L, Sunden SLF, Stone RT and Crawford AM (1994) The Booroola fecundity $\left(\right.$ Fec $\left.^{B}\right)$ gene maps to sheep chromosome 6 Genonics $22148-153$

Piper LR and Bindon BM (1982) Genetic segregation for fecundity in Booroola Merino sheep Proceedings of the World Congress on Sheep and Cattle Breeding $\mathbf{1}$ 395-400

Roberts RM, Baumach GA, Buhi WC, Denny JB, Fitzgerald LA, Babelyn SF and Horst MN (1984) Analysis of membrane polypeptides by two dimensional polyacrylamide gel electrophoresis. In Molecular and Chemical Characterisation of Membrane Receptors pp 61-113 Eds CJ Wenter and LC Harrison. AR Liss, New York

Savion N and Gospodarowicz D (1980) Patterns of cellular peptide synthesis by cultured bovine granulosa cells Endocrinology 107 1799-1807

Shackell GH, Hudson N, Heath DA, Lun S, Shaw L, Condell L, Blay LR and McNatty KP (1993) Plasma gonadotropin concentrations and ovarian characteristics in Inverdale ewes that are heterozygous for a major gene $\left(\mathrm{Fec} \mathrm{X}^{\mathrm{I}}\right)$ on the $\mathrm{X}$ chromosome that influences ovulation rate Biology of Reproduction 48 1150-1156

Spicer L and Stewart RE (1996) Interactions among basic fibroblast growth factor, insulin and IGF on cell numbers and steroidogenesis of bovine thecal cells. Role of $\mathrm{IGF}_{1}$ receptors Biology of Reproduction 54 255-263

Terqui M, Berthelot F and Driancourt MA (1988) Morphological and 
functional features of ovine follicles in perfusion with pulsatile hormone delivery Reproduction Nutrition Development 28 1093-1104

Vanderhyden BC, Cohen JN and Morley P (1993) Mouse oocytes regulate granulosa cell steroidogenesis Endocrinology 133 423-426

Vannier B, Loosfelt H, Meduri G, Pichon C and Milgrom E (1996) Antihuman FSH receptor monoclonal antibodies: immunochemical and immunocytochemical characterisation of the receptor Biochemistry 35 1358-1366

Webb R and England BG (1982) Identification of the ovulatory follicle in the ewe: associated changes in follicular size, thecal and granulosa cell LH receptors, antral fluid steroids and circulating hormones during the preovulatory period Endocrinology 110 873-881

Webb R, Gauld IK and Driancourt MA (1989) Morphological and functional characterisation of large antral follicles in three breeds of sheep with different ovulation rates Journal of Reproduction and Fertility 87 243-255

Webb R, Driancourt MA and Hanrahan JP (1998) Ovulation rate in the ewe: mechanisms underlying genetic variations Proceedings of the 6th World Congress on Genetics Applied to Livestock Production 27 3-10 